\title{
REVITALISASI PELAPORAN KEUANGAN PONDOK PESANTREN
}

\author{
Norsain $^{1)}$, Moh. Faisol ${ }^{2}$ \\ 1),2) Universitas Wiraraja \\ ${ }^{1)}$ Email: norsain@yahoo.com \\ ${ }^{2)}$ Email: faisol114@wiraraja.ac.id
}

\begin{abstract}
Abstrak
Akuntabilitas pelaporan keuangan pondok pesantren menjadi viral setelah Ikatan Akuntan Indonesia mengeluarkan Pedoman Akuntansi Pondok Pesantren. Pelaporan keuangan pesantren menjadi penting untuk ditunaikan sebagai bentuk transparansi akuntabilitas pondok pesantren kepada pemilik (yayasan), mengingat pondok pesantren mengelola keuangan umat (mayarakat umum). Kondisinya adalah Yayasan Pondok Pesantren Inabah XIX Surabaya belum melakukan pelaporan keuangan secara utuh, yang meliputi laporan neraca, laporan operasional, dan laporan arus kas. Dengan demikian, keberadaan kegiatan Revitalisasi Pelaporan Keuangan Dalam Meningkatkan Akuntabilitas Pelaporan Pondok Pesantren adalah penting untuk dilakukan. Kegiatan ini akan dilakukan dalam bentuk pelatihan dengan rangkaian kegiatan, antara lain adalah penyusunan modul laporan keuangan, sosialisasi penyusunan pelaporan keuangan, evaluasi dan monitoring. Hasil dari pengabdian ini adalah peningkatan pemahaman pemilik yayasan dalam mengelola keuangan, khususnya dalam menyusun laporan keuangan. Hal ini dapat dilihat pasca dilakukannya sosialisasi tentang pentingnya laporan keuangan, pengelola mampu menyusun laporan keungan secara mandiri.
\end{abstract}

Kata Kunci: Akuntabilitas, Pelaporan Keuangan Pondok Pesantren, Transparansi

\section{Pendahuluan}

Pondok pesantren merupakan lembaga yang memiliki fungsi dan kedudukan yang khas dalam pendidikan keagamaan yang ada di Indonesia. Lembaga ini memiliki ciri khas di mana segala keputusan terkait dengan aktifitas yang ada di pesantren tersentral pada seorang kyai, inilah perbedaan pesantren dengan lembaga yang lain. Perkembangan pondok pesantren terus mengalami peningkatan, hal ini sebagai bukti bahwa pesantren memiliki dampak pada kehidupan masyarakat Indonesia. Perkembangan tersebut tidak terlepas dari peran serta kondisi sosial, ekonomi, politik, budaya, dan faktor lingkungan eksternal yang lain.

Perkembangan tersebut juga harus simetris dengan kemampuan pesantren dalam mengelola keuangan, mengingat pesantren memiliki banyak penerimaan yang tidak terduga (pendapatan lain-lain), dan beberapa unit bisnis seperti halnya kopontren (koperasi pondok pesantren). Kemampuan dalam mengelola keuangan pondok pesantren menjadi salah satu indikator bahwa pesantren tersebut memiliki tata kelola yang baik. Tata kelola yang baik, khususnya di bidang keuangan yang dilaksanakan oleh pengelola merupakan wujud pertanggungjawab pondok pesantren dalam mengelola dana umat ataupun uang pribadi kyai secara transparan dan akuntabel yang ditujukan kepada pemilik pondok pesantren.

Akuntansi merupakan salah satu alat yang dapat digunakan untuk menghasilkan laporan keuangan pesantren yang transparan dan 
akuntabel. Sistem penganggaran, pengalokasian anggaran, dan pelaporan akan membuat pesantren lebih tertata dan tertib dalam mengelola dan mengalokasikan setiap dana yang dimiliki. Tertibnya penggunaan dana yang dikemas dalam sistem pencatatan akuntansi dapat memberikan informasi yang akurat dan cepat, sehingga pengambilan keputusan yang menggunakan dasar informasi keuangan akan lebih cepat dan tepat sasaran.

Tujuan laporan keuangan yang disajikan dan disusun oleh pondok pesantren adalah media pertanggungjawaban pesantren dalam mengelola dan mengalokasikan keuangan pesantren setiap periode. Hal tersebut untuk memberikan informasi yang akurat dan tepat tentang arus kas, kinerja, posisi keuangan, dan informasi lainnya yang bermanfaat bagi pengguna laporan keuangan, khususnya kyai dalam membuat keputusan dan kebijakan pengelolaan keuangan pesantren. Di sisi lain, laporan keuangan juga sebagai bentuk tanggung jawab pengurus yayasan pondok pesantren atas penggunaan sumber daya yang dipercayakan kepadanya. Atas dasar tersebut, maka kami memandang perlu untuk melakukan pengabdian masyarakat dengan mengadakan kegiatan "Revitalisasi Pelaporan Keuangan Dalam Meningkatkan Akuntabilitas Pelaporan Pondok Pesantren"

Kegiatan pengabdian ini bertujuan untuk (1) memberikan pemahaman teknis menyusun laporan keuangan yayasan pondok pesantren yang sesuai dengan standar pelaporan keuangan pondok pesantren; (2) mewujudkan tercapainya transparansi dan akuntabilitas sesuai dengan UU Yayasan; dan (3) Universitas Wiraraja menjadi pusat konsultasi akuntabilitas podok pesantren baik di berbagai daerah umunya dan Sumenep khususnya.

\section{Metode}

Melihat kondisi yang ada di Yayasan Pondok Pesantren Inabah XIX yang pada saat ini masih belum membuat laporan keuangan secara utuh seperti laporan neraca, laporan operasional, dan laporan arus kas, hal ini dikarenakan pengelola menganggap bahwa dana yang digunakan banyak bersumber dari uang pribadi kyai sehingga tidak perlu dibuatkan laporan keuangan. Untuk mengatasi masalah tersebut, terdapat beberapa metode dan tahapan yang dapat dilakukan agar kegiatan pengabdian ini berjalan sesuai dengan yang diharapkan, antara lain adalah sebagai berikut.

a. Menyusun modul pelaporan keuangan

Sebagai salah satu media untuk melakukan transfer knowledge kepada pemilik dan pengelola keuangan pondok pesantren, maka perlu disusun modul pelaporan keuangan pondok pesantren. Adapun materi yang perlu ada di dalam modul tersebut adalah pengantar tentan pentingnya laporan keuangan, jenis-jenis laporan keuangan, dan case study.

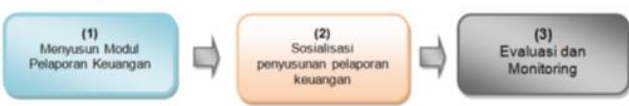

Gambar 1.1 Metode dan tahapan penyelesaian masalah

b. Melakukan sosialisasi penyusunan pelaporan keuangan

Sosialiasasi pelaporan keuangan pondok pesantren dalam meningkatkan akuntabilitas pelaporan keuangan kepada pemilik dan pengelola keuangan. Kegiatan ini dilakukan dalam kurun waktu 1 hari di dalam ruangan tertutup dengan di dukung fasilitas berupa bangku, meja, laptop, LCD Projector, Pointer, Slide (PPT), modul pelaporan keuangan pondok pesantren.

c. Melakukan Evaluasi 
Evaluasi dilakukan untuk menilai, apakah penyelesaian masalah yang dilakukan ini sudah efektif atau tidak, dan lain-lain.

\section{Hasil dan Pembahasan}

Yayasan Pondok Pesantren Inabah XIX Surabaya merupakan suatu entitas yang menurut kaca mata akuntansi penting untuk menyusun laporan keuangan. Halim (2008) menyatakan "asumsi entitas akuntansi menetapkan bahwa semua transaksi keuangan yang diakutansikan adalah yang berkaitan dengan entitas (kesatuan atau organisasi) yang dilaporakan". Sebagai entitas yayasan tersebut secara otomatis terpisah kekayaannya dengan pemilik/ pengelolanya, sehingga tidak berlaku hukum kekayaan yayasan adalah kekayaan pemilik.

Lebih dari itu, yayasan tersebut juga menerima bantuan dari masyarakat untuk pembangunan pesantren, maka secara otomatis akan menyusun laporan keuangan sebagai bentuk pertanggungjawaban pengelola pesantren kepada para pemberi bantuan tersebut. Keberadaan laporan keuangan pada yayasan tersebut menjadi jawaban atas adanya kewajiban akuntabilitas. Di mana saat ini yayasan masih belum mandiri dalam menyusun laporan keuangan sesuai dengan standar akuntansi keuangan yang berlaku, yaitu standar akuntansi entitas tanpa akuntabilitas publik atau pedoman penyusunan laporan keuangan pondok pesantren. Pengabdian ini juga tentunya sebagai bentuk akselerasi akademisi (pengabdi) untuk turut mensosialisasikan dan mengedukasi tentang pentingnya laporan keuangan bagi yayasan.

Saat ini yayasan tengah menyusun laporan keuangan berupa laporan laba rugi, laporan perubahan ekuitas, dan laporan posisi keuangan, namun dibantu oleh pihak ketiga atau tergantung kepada mereka. Sementara setiap harinya yayasan hanya mampu melakukan pencatatan akuntansi atas transaksi yang terjadi berupa arus kas. Karena keterbatasan sumber daya yang ada, mereka tidak mampu menyusun laporan keuangan sebagaimana yang diharuskan oleh standar akuntansi keuangan.

Berbekal informasi tersebut pengabdi melakukan sosialisasi tentang penyusunan laporan keuangan pada pondok pesantren yang berbentuk yayasan. Sosialisasi dilakukan pertama kali secara personal kepada salah satu pengelola saat berkunjung ke Sumenep. Pengabdi (Pak Norsain) menyampaikan bahwa laporan keuangan bagi yayasan merupakan keharusan, hal ini terkait dengan kewajiban untuk melakukan pertanggungjawaban kepada para pemberi bantuan, di samping juga sebagai bahan untuk melakukan kewajiban perpajakan yaitu melaporkan SPT. Atas dasar itu pengelola menyambut baik adanya kegiatan ini tentunya bermanfaat bagi mereka yang selama ini belum melakukan penyusunan laporan keuangan secara mandiri dan juga tidak memisahkan kekayaan entitas (yayasan) dan pemiliknya. Mengutip pernyataan Pak Kaum

...kami bersyukur pak. Kami senang sekali kalau bapak akan bantu kami dalam menyusun laporan keuangan. Apalagi nanti dilanjut dengan kegiatan sosialisasi kepada kami. Kami diajari bagaimana membuat laporan keuangan yang baik. Kami beneran bingung pak.

Pengabdian masyarakat yang dilakukan ini menjadi angin segar bagi pengelola pondok pesantren, pasalnya mereka kebingungan dalam menyusun laporan keuangan yang baik (sesuai dengan standar) sehingga dengan adanya bantuan dari pengabdi untuk melakukan perbaikan dan sosialisasi tata cara menyusun laporan keuangan bagi yayasan mereka mendapatkan sebuah solusi.

Lebih lanjut, pengabdi melakukan sosialisasi penyusunan laporan keuangan pada yayasan tersebut pada tanggal 14 Oktober 2019 
selama 1 hari dengan rangkaian kegiatan sebagai berikut.

Tabel 1.2 Kegiatan Sosialisasi

\begin{tabular}{|c|c|c|}
\hline Waktu & Kegiatan & Keterangan \\
\hline $\begin{array}{c}14 \\
\text { Oktober } \\
2019\end{array}$ & $\begin{array}{l}\text { Penyampaian materi I: } \\
\text { Pentingnya Laporan } \\
\text { Keuangan pada } \\
\text { Yayasan }\end{array}$ & Norsain \\
\hline $\begin{array}{c}14 \\
\text { Oktober } \\
2019 \\
\end{array}$ & $\begin{array}{l}\text { Penyampaian materi II: } \\
\text { Akuntansi Yayasan }\end{array}$ & Norsain \\
\hline $\begin{array}{c}14 \\
\text { Oktober } \\
2019\end{array}$ & $\begin{array}{l}\text { Penyampaian materi } \\
\text { III: } \\
\text { Simulasi aplikasi } \\
\text { laporan keuangan } \\
\text { yayasan }\end{array}$ & $\begin{array}{l}\text { Moh. Faisol } \\
\text { Jamil }\end{array}$ \\
\hline
\end{tabular}

Kegiatan sosialisasi tentang penyusunan laporan keuangan sebagaimana pada tabel 1.2 di atas dibagi menjadi tiga tahap. Secara detail akan dijelaskan pada pembahasan berikut ini.

Tahap pertama, pentingnya laporan keuangan yayasan. Pengabdi memberikan penjelasan sekaligus doktrin tentang pentingnya laporan keuangan bagi pengelola yayasan. Di mana yayasan kemiliki kewajiban untuk menyusun laporan keuangan sebagai dasar untuk memberika informasi keuangan kepada stakeholder (ketua yayasan ataupun pengasuh pondok pesantren), di samping juga kepada para pemberi bantuan. Informasi tersebut akan memberikan manfaat bagi pengasuh dalam mengambil keputusan, misalnya antara membangun gedung atau tidak (hal ini dapat diperoleh dari informasi asset yang dimiliki, baik berupa kas ataupun gedung yang ada serta kewajiban yang dimiliki). Kepada para pemberi bantuan mereka juga akan menjadi lebih percaya atas informasi tersebut sebagai cerminan dari alokasi bantuan yang sudah diberikan kepada yayasan.

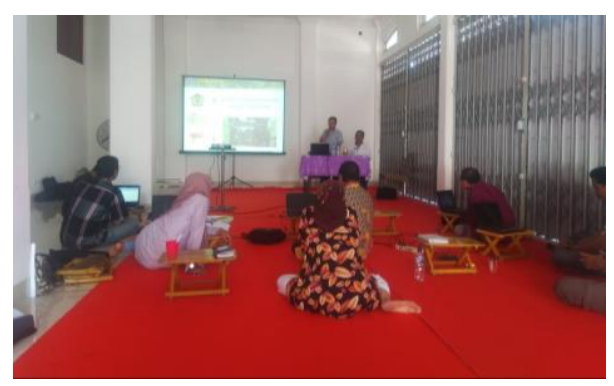

Gambar 1.1 Kegiatan Sosialisasi

Berikutnya, pengabdi juga menegaskan tentang yayasan harus menyusun laporan keuangan karena berkaitan dengan pelaporan SPT tahunan. Di mana setiap yayasan wajib melakukan pelaporan SPT tahunan sebagai entitas kepada dirjen pajak atas sisa hasil usaha yang dijalankan selama 1 tahun akuntansi. Walapun yayasan tidak ada kewajiban pajak (melainkan yang dikecualikan), namun yayasan wajib untuk melaporkan SPT. Pengecualian yang dimaksud adalah jika yayasan memiliki sisa lebih yayasan dalam kurun waktu 4 tahun, maka tidak dikenakan pajak dengan syarat digunakan untuk pembangunan gedung dan sarana prasarana yayasan (pajak.go.id).

Penjelasan tersebut memberikan pesan kepada pengelola dan pemilik pesantren bahwa laporan keuangan itu penting bagi mereka sebagai entitas. Hal tersebut sebagaimana diungkapkan oleh Pak Umat

Begitu ya pak. Saya baru tau kalau seperti itu. Walah pak, kok gak dari dulu ketemu Pak Norsain ya (sambil senyum). Insya'allah dari sekarang pak kami akan tertib.

Kemaren kami juga kaget, liat kekayaan yayasan kok banyak banget. Heran saya.

Pak Umat juga baru menyadari pentingnya laporan keuangan sesuai standar kegunaan dan manfaatnya bagi pemilik dan pengelola yayasan. Beliau sebelumnya belum mengetahui banyak tentang laporan keuangan yayasan, mereka dari dulu hanya mengandalkan sistem pencatatan berupa arus kas, yang memberikan informasi jumlah 
penerimaan dan pengeluaran uang yayasan. Oleh karena itu, beliau juga memiliki komitmen ke depan untuk menyusun laporan keuangan sesuai dengan standar yang berlaku.

Kesadaran untuk membuat laporan keuangan terilhami dengan kondisi kekayaan yayasan yang semakin banyak serta kekayaan pribadi yang menyatu dengan kekayaan yayasan. Beliau beranggapan bahwa dengan kondisi keyakayaan yayasan yang semakin banyak, dan tidak dipisahkan dari kepemilikan pribadi kemungkinan besar ke depan akan terjadi sengketa. Lantas untuk menghindari hal yang tidak diinginkan tersebut, beliau berinisiasi untuk tertib dalam pelaporan keuangan dan juga sebagai bentuk transparansi dan akuntabilitas kepada para pemberi bantuan.

Tahap kedua, akuntansi yayasan. Pengabdi menyampaikan materi ini kepada 11 orang peserta yang mengikuti kegiatan dengan mengawali memperkenalkan siklus akuntansi: jurnal, posting buku besar, neraca penyesuaian, dan laporan keuangan.

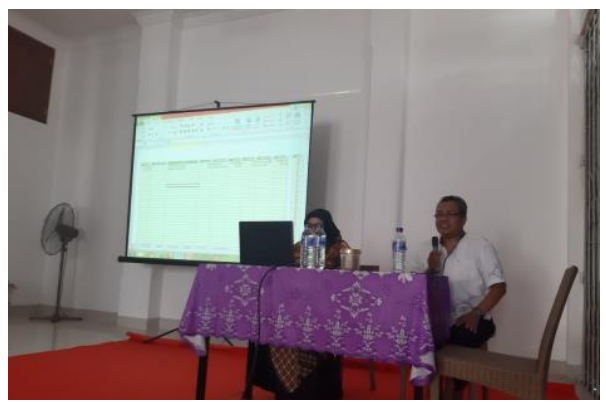

Gambar 1.2 Penjelasan Materi II

Kegiatan ini berlangsung dalam kurun waktu 90 menit. Materi ini akan memberikan gambaran secara manual bagaimana laporan keuangan yayasan itu terbentuk. Dengan bekal pengetahuan logika tersebut peserta memahami bahwa kunci dari laporan keuangan adalah pada saat mereka melakukan jurnal atas transaksi-transaksi yang terjadi.
Tahap ketiga, simulasi aplikasi laporan keuangan dengan menggunakan excel. Materi yang disampaikan oleh pengabdi (Bu Jamil dan Pak Faisol) ini melanjutkan materi yang sudah disampaikan pada tahap kedua. Pada materi ini pengabdi menjelaskan penggunaan sistem aplikasi excel dalam menyusun laporan keuangan sehingga lebig efektif dan efisien.

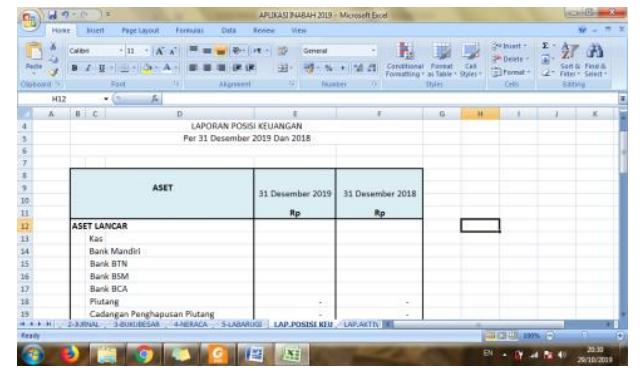

Gambar 1.3 Aplikasi Excel

Aplikasi excel yang dibuat oleh pengabdi cukup memberikan arahan kepada peserta sebagai pengelola yayasan tentang berbagai akun yang ada pada yayasan tersebut, kemudian memberikan arahan tata cara entry data pada saat melakukan jurnal atas transaksitransaksi yang terjadi. Dengan melakukan aktifitas tersebut pengelola secara mudah mampu melihat laporan keuangan secara otomatis tanpa harus menyusun laporan keuangan satu persatu.

Sebagai pemula tentunya dengan aplikasi pelaporan keuangan seperti ini akan membantu mereka dalam menyusun laporan keuangan. Mengutip penrtanyataan Pak Kaum sebagai peserta

Lho... enak toh pak kalo seperti ini. Berrarti kita ini cuma entry jurnal setelah itu sudah bisa liat saldo. Laporan keuangan selesai.

Penyataan Pak Kaum mengamini keberadaan aplikasi excel dalam penyusunan laporan keuangan, karena dengan aplikasi tersebut beliau merasa mudah menyusun laporan keuangan dan mengetahui informasi saldo akhir dari masing-masing akun yang ada. Kenyataannya laporan keuangan yang 
dibanyangkan rumit ternyata hanya bermodal 'penyesuaian kode akun dan entry jurnal", maka laporan keuangan secara otomatis akan tersusun dengan sendirinya.

Alhasil, pengabdian ini memberikan dampak yang positif bagi pengelola dan pemilik yayasan dalam menyusun laporan keuangan sesuai dengan satandar yang ada secara mudah dan efektif. Mereka dengan adanya aplikasi tersebut berkomitmen akan mempu menyusun laporan keuangan secara mandiri untuk tahun 2019. Namun, demikian pengelola tetap melakukan komunikasi dengan pengabdi terkait dengan hasil jadi laporan keuangan tahun 2019 nanti yang mereka susun secara mandiri. Mengutip pernyataan Pak Kaum

Kami bisa Pak. Tahun 2019 kami buat sendiri laporannya. Tapi nanti sambil dilihat ya pak (senyum penuh semangat).

Komitmen itulah juga menjadi kenikmatan tersendiri bagi pengabdi dalam menebarkan keilmuan sebagai insan akademika. Bahwasanya produk pengabdi berhasil diterapkan dan bermanfaat bagi yayasan khususnya dalam menyusun laporan keuangan.

\section{Simpulan}

Penguatan yayasan dalam pelaporan keuangan sesuai dengan standar akuntansi keuangan yang berlaku disadari oleh pemilik dan pengelola yayasan sebagai alat untuk memisahkan harta yayasan dan pribadi, sebagai alat untuk memenuhi kewajiban perpajakan dan pertanggungjawaban kepada stakeholder. Pemilik dan pengelola yayasan memberikan apresiasi karena mereka sudah diberikan informasi tentang tata cara menyusun laporan keuangan yang lebih praktis dengan menggunakan aplikasi excel.

\section{Daftar Pustaka}

Halim, A. 2012. Akuntansi Sektor Publik: Akuntansi Keuangan Daerah, edisi ke-4. Jakarta: Salemba Empat.

Ikatan Akuntan Indonesia. 2018. Pedoman Akuntansi Pondok Pesantren. Jakarta: IAI.

Pajak.go.id. 